\title{
IMMUNIZATION WITH NATIVE AND COBALT 60-IRRADIATED Crotalus durissus terrificus VENOM IN SWISS MICE: ASSESSMENT OF THE NEUTRALIZING POTENCY OF ANTISERA
}

\author{
FERREIRA JUNIOR R. S. (1,2), NASCIMENTO N. (3), MARTINEZ J. C. (4),
} ALVES J. B. (3), MEIRA D. A. (1), BARRAVIERA B. $(1,2)$.

(1) Department of Tropical Diseases, Botucatu School of Medicine, São Paulo State University, UNESP, Botucatu, São Paulo, Brazil; (2) Center for the Study of Venoms and Venomous Animals - CEVAP, São Paulo State University, UNESP, Botucatu, São Paulo, Brazil; (3) Radiobiology Supervision - Nuclear Energy Research Institute (IPEN/CNEN/SP), São Paulo, Brazil; (4) Department of Production Engineering, School of Engineering, São Paulo State University, UNESP, Bauru, São Paulo, Brazil.

ABSTRACT: ELISA was used to evaluate, follow, and compare the humoral immune response of Swiss mice during hyperimmunization with natural and Cobalt 60irradiated $\left({ }^{60} \mathrm{Co}\right)$ Crotalus durissus terrificus venom. Potency and neutralization were evaluated by in vitro challenges. After hyperimmunization, immunity was observed by "in vivo" challenge and the side effects were assessed. The animals immunization with one $\mathrm{LD}_{50}$ of the venom was on days one, 15, 21,30, and 45, when blood samples were collected; the challenges occurred on the $60^{\text {th }}$ day. Results showed that ELISA was efficient in evaluating, following, and comparing mouse immune response during hyperimmunization. Serum titers produced with natural venom were similar to those produced with irradiated venom. Immunogenic capacity was maintained after ${ }^{60} \mathrm{Co}$ irradiation. Serum produced from Crotalus durissus terrificus irradiated venom showed higher potency and neutralization capacity than that from natural venom. All antibodies were able to neutralize five $L D_{50}$ from these venoms. Clinical alterations were minimum during hyperimmunization with irradiated venom.

KEY WORDS: hyperimmunization, irradiation, Crotalus durissus terrificus, ELISA, serum neutralization, detoxification.

\section{CORRESPONDENCE TO:}

R. S. FERREIRA JÚNIOR, Centro de Estudos de Venenos e Animais Peçonhentos CEVAP, UNESP, Caixa Postal 577, 18618-000, Botucatu, São Paulo, Brasil.

Email: rseabra@cevap.org.br 
R. S Ferreira Júnior et al. IMMUNIZATION WITH NATIVE AND COBALT 60-IRRADIATED Crotalus durissus terríficus VENOM IN SWISS MICE: ASSESSMENT OF THE NEUTRALIZING POTENCY OF ANTISERA. J. Venom. Anim. Toxins incl. Trop. Dis., 2005, 11, 3, p. 300

\section{INTRODUCTION}

The treatment of accidents caused by snakebites uses heterologous serum from animal plasma, generally equine $(11,27,39)$ and ovine $(18,26,33)$, hiperimmunized with snake venoms (46).

Crotalus durissus terrificus (C.d.t.) venom is poorly immunogenic despite being clearly toxic (12). One of the reasons for obtaining an adequate humoral immune response against this venom is the presence of immunosupressant components $(9$, $12,18,41)$. In addition, the injury suffered by the animals after the injection of crude venom contributes to low productivity of antivenin (34).

Crotoxin, one of the C.d.t. venom components, represents the main obstacle in the production of crotalic antivenom, since its high toxicity causes severe symptoms in serum-productor animals. Systemic reactions, which can also lead the animal to death, are very frequently observed $(8,22)$.

As sera production depends directly on the immunogenic capacity, this problem needs to be solved. Thus, the researchers have been searching for alternatives preparing toxoids by venom biological detoxification, but keeping its immunogenicity $(11,46)$.

In regard to the techniques used in the toxoids preparation for antivenin preparation, innumerous works, in which chemical and/or physical agents were used for this purpose, are found. Among the chemical agents are: carboximetyl cellulose (28): photoxidation in the presence of methylene blue (25); chelating agents (20); formalin (14); iodine (16); glutaraldehide (22); and others. The principal physical agents are: $x-$ ray radiation (19), ultraviolet radiation (44), heat (14), and gamma radiation (23). This last one, according to previous works $(1,6,8,12,13,15,17,21,29,31,33,34,36$, $40,42,43)$, has been proved to be an excellent tool of detoxification, since it is able to decrease the toxicity without altering the immunogenicity. In addition, this radiation does not add any new substance to the venom.

Thus, alternatives to improve the heterologous sera productivity preparing less damaging toxoids and preserving their immunogenic capacity $(11,46)$ have been searched. Therefore, the aims of this work were to compare the humoral immune response, to determine and compare the neutralizing potency and capacity of the serum obtained from mice inoculated with Crotalus durissus terrificus venom in its native and cobalto 60-irradiated form, in order to use these results in the serum production. 
R. S Ferreira Júnior et al. IMMUNIZATION WITH NATIVE AND COBALT 60-IRRADIATED Crotalus durissus terríficus VENOM IN SWISS MICE: ASSESSMENT OF THE NEUTRALIZING POTENCY OF ANTISERA. J. Venom. Anim. Toxins incl. Trop. Dis., 2005, 11, 3, p. 301

\section{MATERIAL AND METHODS}

Crude air-dried venom from a large number of South American rattlesnakes, Crotalus durissus terrificus, was provided from The Center for the Study of Venoms and Venomous Animals - CEVAP - UNESP. Mice were obtained from the colony housed available at the same institute.

\section{Venom irradiation}

Whole C.d.t. venom was dissolved in saline solution $(0.15 \mathrm{M} \mathrm{NaCl}$ adjusted to $\mathrm{pH} 3.0$ with concentrated $\mathrm{HCl}$ ), and its protein concentration adjusted to $2 \mathrm{mg} / \mathrm{ml}$ as determined by the Bradford method (7). Samples were irradiated at a dose of 5,25 KGy/h with 2000 Gy using gamma rays derived from a ${ }^{60} \mathrm{Co}$ source, Gammacell 220 (Atomic Energy Agency of Canada Ltd), in the presence of $\mathrm{O}_{2}$ at room temperature (31). These experiments were performed at the Institute of Nuclear and Energetic Research - IPEN/CNEM/SP.

\section{Production of antibodies}

Three groups of eight Swiss male mice, weighing 18-22 g, were immunized. Each inoculum received a $L D_{50}$ of native (Group I) and irradiated (Group II) Crotalus durissus terrificus venom, corresponding to $0.148 \mu \mathrm{g} / \mathrm{g}$ mice. (31).

The inocula were performed on the first day, using a complete Freund's adjuvant intradermically; on the $15^{\text {th }}$ day, using aluminum hydroxide subcutaneously; and on the $21^{\text {st }}, 30^{\text {th }}$, and $45^{\text {th }}$ days, using PBS intraperitonially.

The control group received the inocula on the same days, but just with the adjuvants. All the animals were inoculated with $200 \mu \mathrm{l}$ of a solution containing $100 \mu \mathrm{l}$ of the excipient and $100 \mu \mathrm{l}$ of the venom diluted in saline solution. The control group received $200 \mu \mathrm{l}$ of a solution containing $100 \mu \mathrm{l}$ of the excipient and $100 \mu \mathrm{l}$ of saline solution.

Before receiving each inoculum, all the animals were bled by the retro-orbital plexus, a sample of $100 \mu \mathrm{l}$ blood was collected and the serum was separated. From each group of animals, a serum pool was prepared, frozen, and kept at $-20^{\circ} \mathrm{C}$.

\section{Enzyme-linked immunoassays (ELISA)}

This assay was performed in order to detect the antibodies produced against native and irradiated C.d.t. venom in the animal sera. They were accomplished on the $15^{\text {th }}$, 
R. S Ferreira Júnior et al. IMMUNIZATION WITH NATIVE AND COBALT 60-IRRADIATED Crotalus durissus terríficus VENOM IN SWISS MICE: ASSESSMENT OF THE NEUTRALIZING POTENCY OF ANTISERA. J. Venom. Anim. Toxins incl. Trop. Dis., 2005, 11, 3, p. 302

$21^{\text {st }}, 30^{\text {th }}, 45^{\text {th }}$, and $60^{\text {th }}$ days, performed as described by Nascimento et al., (31). On the $60^{\text {th }}$ day, the titration of the sera from the two groups studied was performed based on the dilution of 1:200 to 1:204800.

\section{Evaluation of the potency involving in vitro preincubation of serum and venom}

To determine the antivenom potency at the $60^{\text {th }}$ day after the first inoculation, an aliquot of $100 \mu \mathrm{l}$ of the pool of each serum was incubated with $100 \mu \mathrm{l}$ of a solution containing variable quantities of native venom. For this purpose, different dilutions in PBS equivalent to $1,3,5,10$, and $15 \mathrm{LD}_{50}$ were prepared. The incubation was performed in Eppendorf tubes kept in an incubator at $37^{\circ} \mathrm{C}$ for 30 minutes (26). Then, $200 \mu \mathrm{l}$ of each solution was intraperitonially inoculated into mice.

For control, eight mice were inoculated: four received $200 \mu \mathrm{l}$ of a solution containing five $L D_{50}$ of the native venom diluted in PBS to confirm its toxicity, the remaining animals received only $100 \mu \mathrm{l}$ of an aliquot of serum diluted in $100 \mu \mathrm{l}$ of PBS, in order to evaluate its innocuousness. After 48 hours, the mortality rate was recorded.

\section{Protective ability of the antivenom}

To determine the antivenom neutralization capacity at the $60^{\text {th }}$ day after the first inoculation, a constant amount of C.d.t. venom $(74 \mu \mathrm{g} / \mathrm{ml})$ was mixed with different dilution of Swiss mice antivenom raised against the non-irradiated (native venom) or irradiated venom. Following incubation at $37^{\circ} \mathrm{C}$ for 30 minutes, the mixtures were injected i.p. into mice at a dose of $10 \mu \mathrm{l} / \mathrm{g}$ body weight (26). The toxin neutralizing capacity ( $\mu \mathrm{g}$ of toxin $/ \mathrm{ml}$ of antivenom) was calculated as described by Kaiser et al., (24).

For control, eight mice were inoculated: four received $200 \mu \mathrm{l}$ of a solution containing five $L D_{50}$ of the native venom diluted in PBS to confirm its toxicity, the remaining animals received only $100 \mu \mathrm{l}$ of an aliquot of serum diluted in $100 \mu \mathrm{l}$ PBS in order to evaluate its innocuousness. After 48 hours, the mortality rate was recorded.

\section{Evaluation of the "in vivo" neutralizing capacity}

In order to verify the "in vitro" neutralizing capacity of the antibodies produced by the animals, at the end of the immunization process, four mice of each group studied were weighed and individually challenged with $5 L D_{50}$ of the native venom diluted in 
R. S Ferreira Júnior et al. IMMUNIZATION WITH NATIVE AND COBALT 60-IRRADIATED Crotalus durissus terríficus VENOM IN SWISS MICE: ASSESSMENT OF THE NEUTRALIZING POTENCY OF ANTISERA. J. Venom. Anim. Toxins incl. Trop. Dis., 2005, 11, 3, p. 303

PBS. Each animal received, intraperitonially, $200 \mu \mathrm{l}$ of this solution. After 48 hours, the mortality rate was recorded.

\section{Statistical analysis}

The significance of differences between the means of two experimental groups was determined by the Snedecor's F-test. Values of $p<0.05$ were considered statistically significant (15).

\section{RESULTS}

Results of the ELISA method for the serum produced from native and irradiated Crotalus durissus terrificus venom

\section{Enzyme-linked immunoassays (ELISA)}

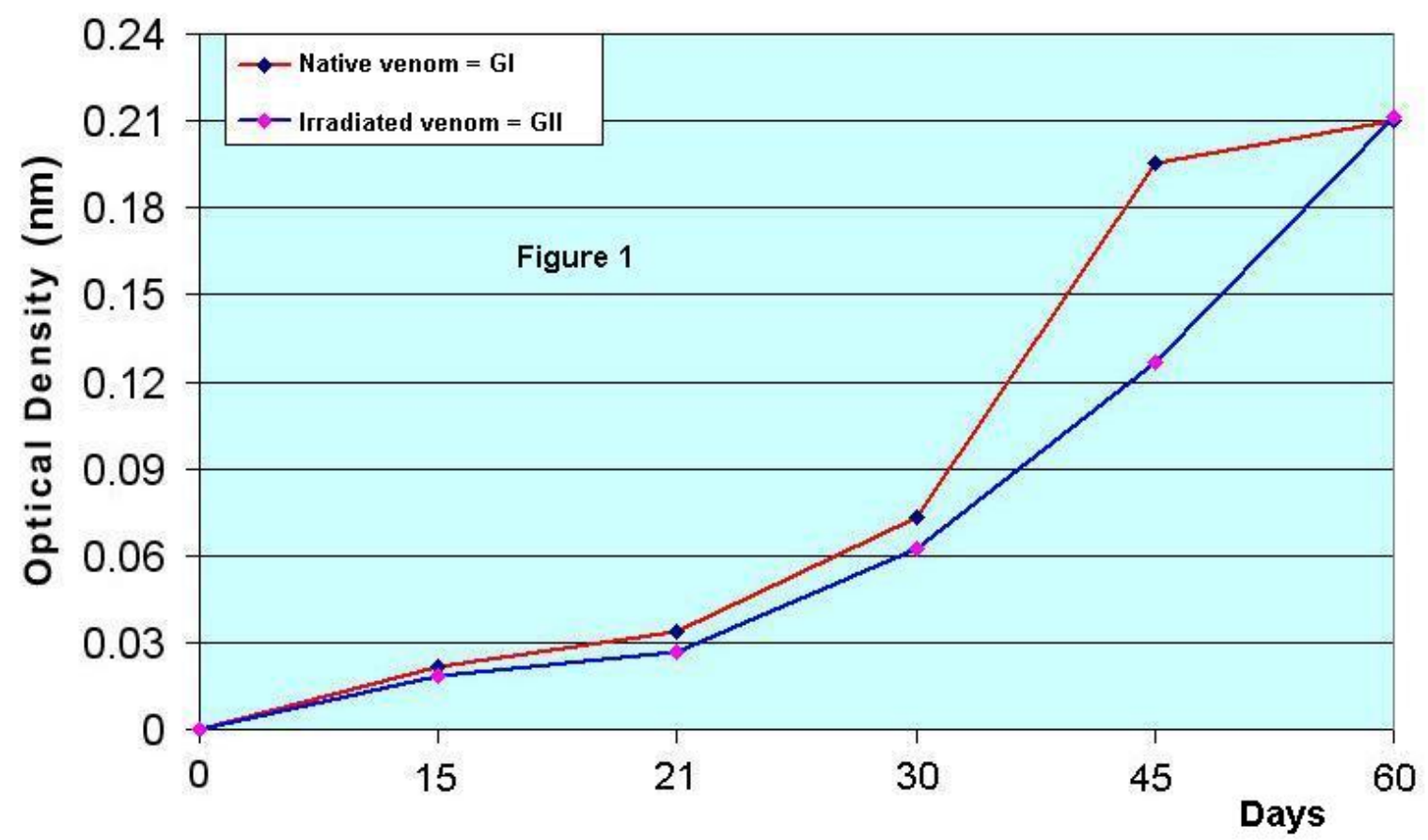

G I = G II; $F_{\text {Lines }}=1.89<F_{\text {Critical }}=7.71(\alpha=5 \%)$.

$D_{0} \neq D_{15} \neq D_{21} \neq D_{30} \neq D_{45} \neq D_{60} ; F_{\text {Columns }}=34.16>F_{\text {Critical }}=6.39(\alpha=5 \%)$.

Figure 1: Distribution of the optical densities $(\mathrm{nm})$ mean values in the ELISA test, in different moments, using serum extracted from animals inoculated with native (GI) and cobalt 60-irradiated (GII) venom, diluted in 1:200. 
R. S Ferreira Júnior et al. IMMUNIZATION WITH NATIVE AND COBALT 60-IRRADIATED Crotalus durissus terríficus VENOM IN SWISS MICE: ASSESSMENT OF THE NEUTRALIZING POTENCY OF ANTISERA. J. Venom. Anim. Toxins incl. Trop. Dis., 2005, 11, 3, p. 304

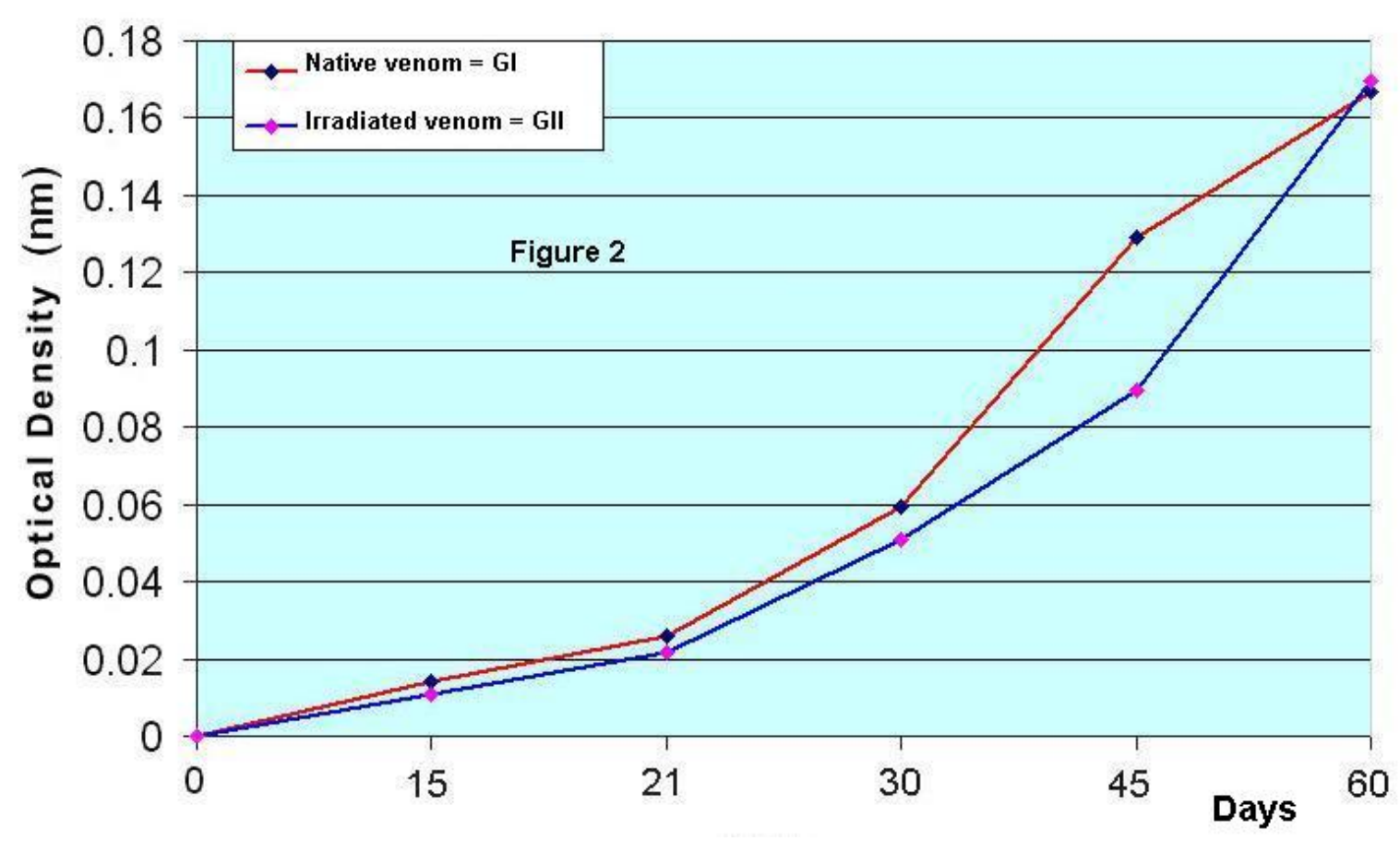

G I = G II; $F_{\text {Lines }}=2.04<F_{\text {Critical }}=7.71(\alpha=5 \%)$.

$D_{0} \neq D_{15} \neq D_{21} \neq D_{30} \neq D_{45} \neq D_{60} ; F_{\text {Columns }}=60.81>F_{\text {Critical }}=6.39(\alpha=5 \%)$.

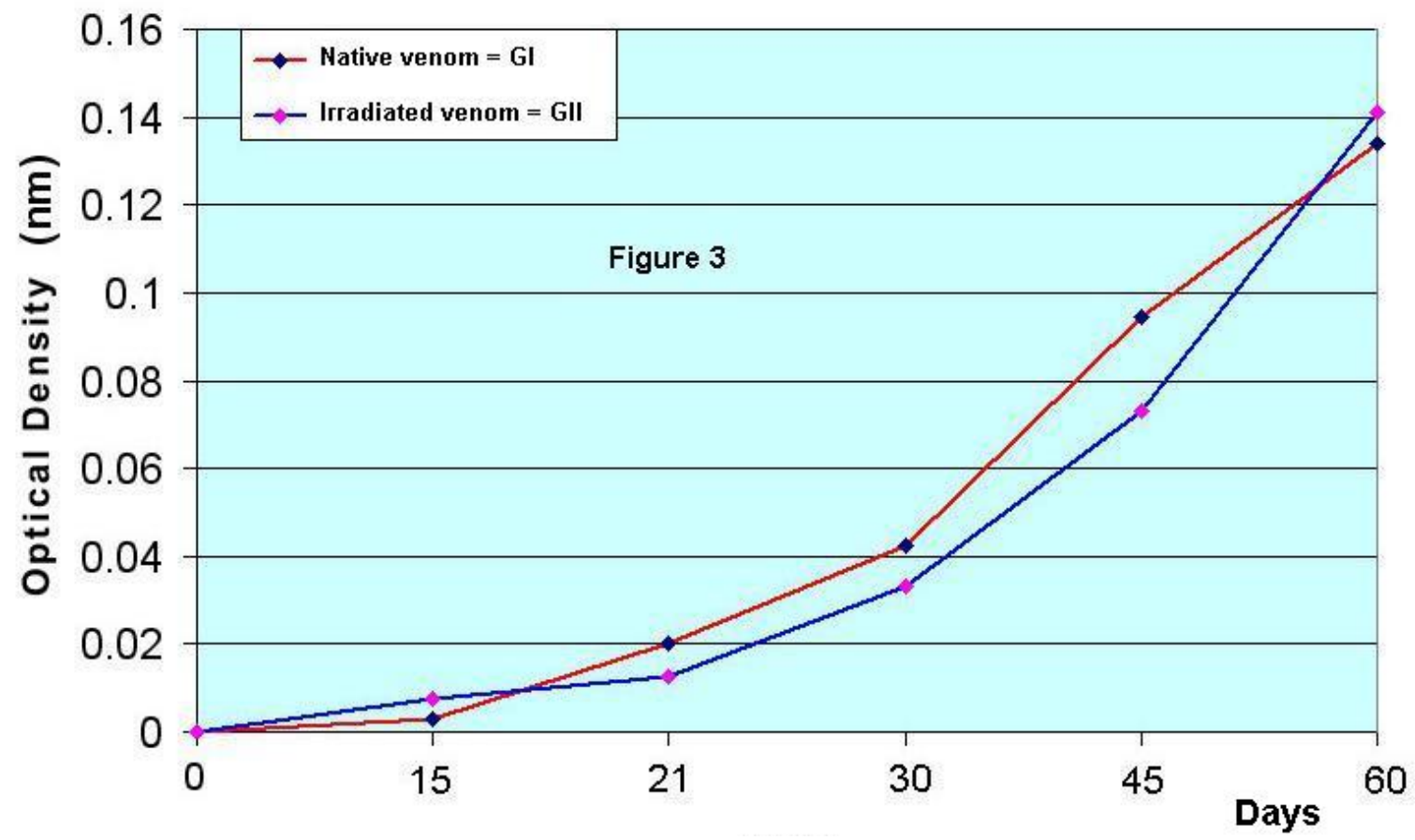

$\mathrm{GI}=\mathrm{G} \mathrm{II} ; \mathrm{F}_{\text {Lines }}=1.11<\mathrm{F}_{\text {Critical }}=7.71(\alpha=5 \%)$.

$D_{0} \neq D_{15} \neq D_{21} \neq D_{30} \neq D_{45} \neq D_{60} ; F_{\text {Columns }}=89.71>F_{\text {Critical }}=6.39(\alpha=5 \%)$.

Figures 2 and 3: Distribution of the optical densities $(\mathrm{nm})$ mean values in the ELISA test, in different moments, using serum extracted from animals inoculated with native (GI) and cobalt 60-irradiated (GII) venom, diluted in 1:400 and 1:800 respectively. 
R. S Ferreira Júnior et al. IMMUNIZATION WITH NATIVE AND COBALT 60-IRRADIATED Crotalus durissus terríficus VENOM IN SWISS MICE: ASSESSMENT OF THE NEUTRALIZING POTENCY OF ANTISERA. J. Venom. Anim. Toxins incl. Trop. Dis., 2005, 11, 3, p. 305

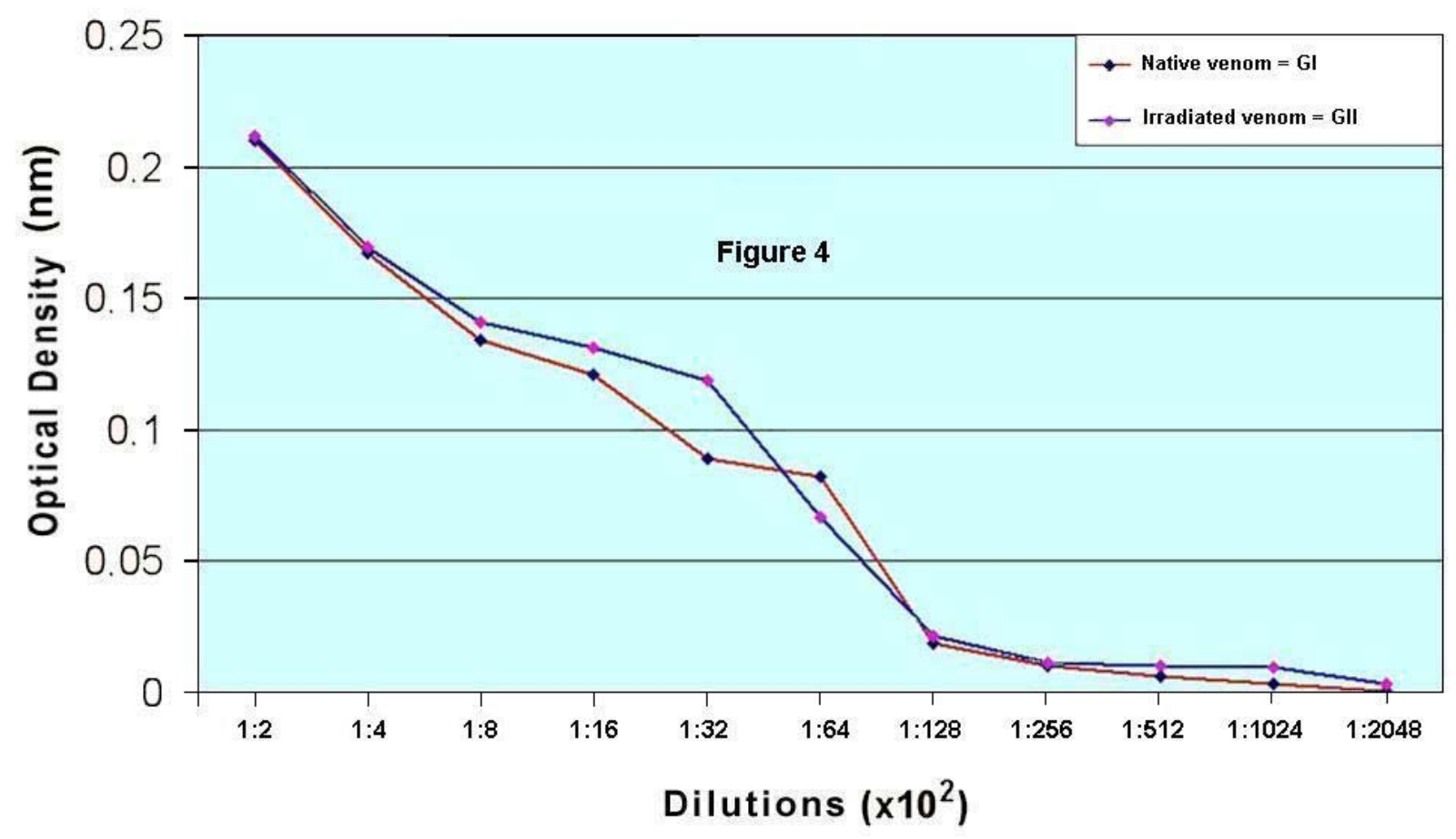

G I = G II; $F_{\text {Lines }}=2.36<F_{\text {Critical }}=4.96(\alpha=5 \%)$.

$D_{1: 2} \neq D_{1: 4} \neq D_{1: 8} \neq D_{1: 16} \neq D_{1: 32} \neq D_{1: 64} \neq D_{1: 128} \neq D_{1: 256} \neq D_{1: 512} \neq D_{1: 1024} \neq D_{1: 2048}$ $\mathrm{F}_{\text {Columns }}=202.86>\mathrm{F}_{\text {Critical }}=2.98(\alpha=5 \%),\left(\mathrm{Dx} 10^{2}\right)$

Figure 4: Distribution of the optical densities mean values in the ELISA test, at the $60^{\text {th }}$ day, in different dilutions (1:200 to 1:204800), using serum extracted from animals inoculated with native (GI) and cobalt 60-irradiated (GII) venom. 
R. S Ferreira Júnior et al. IMMUNIZATION WITH NATIVE AND COBALT 60-IRRADIATED Crotalus durissus terríficus VENOM IN SWISS MICE: ASSESSMENT OF THE NEUTRALIZING POTENCY OF ANTISERA. J. Venom. Anim. Toxins incl. Trop. Dis., 2005, 11, 3, p. 306

Neutralizing capacity and potency

Table 1: Determination of the potency of Crotalus durissus terrificus antivenom prepared with native venom (GI) or irradiated venom (GII)

\begin{tabular}{ccc}
\hline \multirow{2}{*}{$\begin{array}{c}\text { Venom in } \text { LD }_{50} \\
\text { quantity }\end{array}$} & \multicolumn{2}{c}{ Mortality (\%) } \\
\cline { 2 - 3 } 1 & 0 & GII \\
3 & 0 & 0 \\
5 & 50 & 0 \\
10 & 100 & 25 \\
15 & 100 & 75 \\
---- & 0 & 100 \\
1 & 100 & 0 \\
\hline
\end{tabular}

Table 2: Serum dilution for determination of the neutralizing capacity of Crotalus durissus terrificus antivenom prepared with native venom (GI) or irradiated venom (GII).

\begin{tabular}{ccc}
\hline \multirow{2}{*}{ Serum Dilution } & \multicolumn{2}{c}{ Mortality (\%) } \\
\cline { 2 - 3 } & GI & GII \\
\hline Pure & 50 & 25 \\
$1: 5$ & 100 & 50 \\
$1: 10$ & 100 & 75 \\
$1: 40$ & 100 & 75 \\
$1: 80$ & 100 & 100 \\
& 100 & 100 \\
\hline
\end{tabular}


R. S Ferreira Júnior et al. IMMUNIZATION WITH NATIVE AND COBALT 60-IRRADIATED Crotalus durissus terríicus VENOM IN SWISS MICE: ASSESSMENT OF THE NEUTRALIZING POTENCY OF ANTISERA. J. Venom. Anim. Toxins incl. Trop. Dis., 2005, 11, 3, p. 307

We observed that $1.0 \mathrm{ml}$ of the antivenom prepared with C.d.t. irradiated venom could neutralize $296 \mu \mathrm{g}$ of native venom, whereas $1.0 \mathrm{ml}$ of the antivenom prepared with native venom could neutralize only $59.2 \mu \mathrm{g}$.

\section{"In vivo" neutralizing capacity}

From the groups studied, none of the animals died after 48 hours observation.

\section{DISCUSSION}

The most efficient treatment known until the present moment for accidents caused by venomous snakes is the specific heterologous serum $(4,45)$. The production of antivenom has been performed throughout the history in large animals, particularly Equidae in Brazil $(11,22,39,45)$.

The production of specific serum against Crotalus durissus terrificus venom is a difficult process because, despite being toxic, it has an inhibitory effect in the antibodies production $(9,18,37,41)$.

The hiperimmunization with crude venoms can cause important side effects, including death (2). According the same authors, few studies on the importance of the deleterious effects caused by venoms during the hiperimmunization process were performed.

In order to overcome these difficulties, several methods of detoxification have been studied in order to minimize the alterations caused by the venom $(14,16,19,20,22$, $23,25,28,44)$. In addition, the researchers look for alternatives of antibodies production with high quality and the highest seric levels.

In this context, gamma radiation has been showed to be an excellent tool for snake venom attenuation. Some authors $(12,30,31,32)$ verified that, after the irradiation, the C.d.t. venom and its fractions antigenic and immunogenic properties were preserved, and its toxicity was reduced.

Murata et al. (29), using C.d.t. crude venom verified that the irradiation of $2000 \mathrm{~Gy}$ is the ideal dose for snake venoms detoxification, since it keeps many immunological properties. Nascimento et al. $(30,31,32)$ found similar results using purified crotoxin. In the present study, the efficiency of the irradiation technique of Crotalus durissus terrificus venom with ${ }^{60} \mathrm{Co}$ in the production of antivenomous serum in mice was investigated. 
R. S Ferreira Júnior et al. IMMUNIZATION WITH NATIVE AND COBALT 60-IRRADIATED Crotalus durissus terríficus VENOM IN SWISS MICE: ASSESSMENT OF THE NEUTRALIZING POTENCY OF ANTISERA. J. Venom. Anim. Toxins incl. Trop. Dis., 2005, 11, 3, p. 308

The ELISA technique was used in the detection and following of the titer of antibodies during the hiperimmunization process. This technique has been showed to be the method with the best specificity, sensitivity, fastness, simplicity, and low costs $(3,5$, $30,35,38,45)$.

Clissa et al., 1999, evaluated the immunogenic activity of native and irradiated C.d.t. venom in rabbits by the ELISA assay. Nascimento et al. (31) evaluated the ionizing radiation influence on the C.d.t. venom crotoxin. According to these authors the antigenic and immunogenic properties were preserved after the irradiation with cobalt 60.

De Paula et al. (17), studying the production of antivenoms from irradiated C.d.t. crotoxin and crude venom in rabbits, verified that the sera produced were able to recognize the native toxins.

The results obtained showed that the optical density values from the ELISA test to the several dilutions of native and irradiated C.d.t. venom did not show statistical differences between the two groups studied.

It was also verified that the antibodies could be detected 15 days after the first inoculum. On the last day of the experiment, the $60^{\text {th }}$ day, the titration of the antibody levels in the dilutions from 1:200 to 1:204800 was performed. It was observed that there was no statistical difference between the groups evaluated.

The titles of antibodies produced permit the conclusion that both the group of mice hiperimmunized with native venom and the group of mice hiperimmunized with irradiated venom were immunogenic, with production of antibodies able to recognize native C.d.t. venom. These results confirm the data obtained by other authors (12, 32).

Tests of neutralization potency and capacity were performed after the animals of the group studied produced high titers of antibodies.

The "in vitro" neutralization capacity of the serum produced from the irradiated C.d.t. venom was higher than that of the serum produced from native venom.

The serum produced from native C.d.t. venom neutralized $0.592 \mathrm{mg} / \mathrm{ml}$, equivalent to $200 L_{50}$ of the native venom, while the serum produced from the irradiated venom neutralized $5.92 \mathrm{mg} / \mathrm{ml}$, equivalent to $2000 \mathrm{LD}_{50}$ of the native venom.

The results observed in the determination of the sera pool potency showed that, despite the titers of antibodies were similar according to the ELISA assay, the serum produced from the irradiated venom showed to be efficient. 
R. S Ferreira Júnior et al. IMMUNIZATION WITH NATIVE AND COBALT 60-IRRADIATED Crotalus durissus terríficus VENOM IN SWISS MICE: ASSESSMENT OF THE NEUTRALIZING POTENCY OF ANTISERA. J. Venom. Anim. Toxins incl. Trop. Dis., 2005, 11, 3, p. 309

According to Cardi et al. (8), the gamma irradiation proved to be the most successful method for the crotoxin detoxification. These authors (8) suggest that the reduction of toxicity is due to a precocious endocytosis of crotoxin by phagocytic cells, improving the antigen processing. This occurs because the irradiation promotes molecule oxidation facilitating its phagocytosis due to the presence of scavenger receptors in the macrophages surface.

It is known that the antigens, as they enter the organism, suffer an oxidation process by the defensive cells to facilitate the phagocytosis process (36). In irradiated samples, the macrophagus find these molecules oxidated, and therefore, they eliminate this step of the process. A better processing, associated to a faster antigen presentation, makes the immunologic system produce more complete antibodies against a higher number of antigen epitopes (36).

The results observed in this study agree with those already obtained by other authors $(12,30,31,33,34,36)$.

None of the animals from the groups studied died during the "in vivo" tests when challenged with $5 L_{50}$ of the native venom after 48 hours observation.

With regard to the side effects caused by venoms, Carvalho et al. (10), cite the venom and adjuvants toxicity, mainly the Freund's Complete Adjuvant, as the major problem in the production of commercial antivenoms. They cause inflammation and lesions in the inoculum site, contributing to the reduction of the longevity of animals that produce immunoglobulines.

In this experiment, all the mice were daily observed in order to detect clinical alterations and lesions in the inoculation sites. None of the animals died, and no local or systemic alterations were observed.

Therefore, these results demonstrate that the gamma radiation can be used as an important tool for the anticrotalic serum production in the process of animal immunization; since the neutralization capacity and potency of the serum produced from the irradiated venom were higher despite the titers of antibodies found by the immunization process were similar.

\section{ACKNOWLEDGEMENTS}

The authors thank Dr. Silvia Regina Sartori Barraviera, director of The Center for the Study of Venoms and Venomous Animals - CEVAP, São Paulo State University UNESP and Karina Luiz Chamma for technical assistance. 
R. S Ferreira Júnior et al. IMMUNIZATION WITH NATIVE AND COBALT 60-IRRADIATED Crotalus durissus terríificus VENOM IN SWISS MICE: ASSESSMENT OF THE NEUTRALIZING POTENCY OF ANTISERA. J. Venom. Anim. Toxins incl. Trop. Dis., 2005, 11, 3, p. 310

\section{REFERENCES}

1 ADRIANI EP. Irradiation of crotoxin in aqueous solution: the role of the main reactive species in structural and biological alterations. J. Venom. Anim. Toxins, 1996, 2, 168.

2 ÂNGULO Y., ESTRADA R., GUTIÉRREZ JM. Clinical and laboratory alterations in horses during immunization with snake venoms for the production of polyvalent (Crotalinae) antivenom. Toxicon, 1997, 35, 81-90.

3 BARBOSA CF., RODRIGUES RJ., OLORTEGUI CC. Determination of the neutralizing potency of horse antivenom against bothropic and crotalic venoms by indirect enzyme immunassay. Braz. J. Med. Biol. Res., 1995, 28, 1077-80.

4 BARRAVIERA B., LOMONTE B., TARKOWSKI A., HANSON LA., MEIRA DA. Acute-phase reactions, including cytokines, in patients bitten by Bothrops and Crotalus snakes in Brazil. J. Venom. Anim. Toxins, 1995, 1, 11-22.

5 BARRAVIERA B., SARTORI A., PEREIRA DA SILVA MF., KANENO R., PERAÇOLI RMTS. Use of an ELISA assay to evaluate venom, antivenom, IgG and IgM human antibody levels in serum and cerebrospinal fluid from patients bitten by Crotalus durissus terrificus in Brazil. J. Venom. Anim. Toxins, 1996, 2, 14-27.

6 BONI-MITAKE M., COSTA H., SPENCER PJ., VASSILIEFF VS., ROGERO JR. Effects of ${ }^{60} \mathrm{Co}$ gamma radiation on crotamine. Braz. J. Med. Biol. Res., 2001, 34, 1531-3158.

7 BRADFORD MM. A rapid and sensitive method for the quantitation of microgram quantities of protein utilizing the principle of protein-dye binding. Anal. Biochem., 1976, 72, 248-54.

8 CARDI BA., ANDRADE HF., ROGERO JR., NASCIMENTO N. Differential biodistribution of native and $2 \mathrm{kGy}{ }^{60} \mathrm{Co}$ irradiated crotoxin in tissues of CBA/J mice. Natural Toxins, 1998, 6, 19-25.

9 CARDOSO DF., MOTA I. Effect of Crotalus venom on the humoral and cellular immune response. Toxicon, 1997, 35, 607-12.

10 CARVALHO VT., GOMES RT., VIOTTI AP., FREITAS TV. Immunization with liposome-encapsulates Bothrops jararaca venom. Toxicon, 2000, 38, 881-6.

11 CHIPPAUX JP., GOYFFON M. Venoms, antivenoms and immunotherapy. Toxicon, 1998, 36, 823-46. 
R. S Ferreira Júnior et al. IMMUNIZATION WITH NATIVE AND COBALT 60-IRRADIATED Crotalus durissus terríicus VENOM IN SWISS MICE: ASSESSMENT OF THE NEUTRALIZING POTENCY OF ANTISERA. J. Venom. Anim. Toxins incl. Trop. Dis., 2005, 11, 3, p. 311

12 CLISSA PB., NASCIMENTO N., ROGERO JR. Toxicity and immunogenicity of Crotalus durissus terrificus venom treated with different doses of gama rays. Toxicon, 1999, 37, 1131-41.

$13 \mathrm{COSTA} \mathrm{H} .{ }^{60} \mathrm{Co}$ gamma radiation effects on Apis mellifera venom: biochemical, pharmacological, and immunological aspects. J. Venom. Anim. Toxins, 2002, $8,182$.

14 COSTA LM. Estudo comparativo da resposta imune de cavalos ao veneno de Crotalus durissus terrificus, in natura, tratado com formaldeído e submetido à ação térmica. Vac. Soros, 1985, 1, 24-9.

15 COSTA NETO PLO. Estatística. São Paulo: Edgard Blücher, 1999. 264p.

16 DANIEL JP., HENEINE LG., TAVARES CA., NASCIMENTO MC., HENEINE IF. Generation of protective imune sera by Crotalus durissus terrificus detoxified by controled iodination. Braz J. Med. Biol. Res., 1987, 20, 713-20.

17 DE PAULA RA. Attainment and evaluation of antisera raised against irradiated whole crotalic venom or crotoxin in ${ }^{60} \mathrm{Co}$ source. J. Venom. Anim. Toxins, 1996, 2, 166.

18 DOS SANTOS MC., D'IMPERIO-LIMA R., DIAS DA SILVA W. Influence of Crotalus venom on the response to sheep red blood cells. Braz. J. Med. Biol. Res., 1986, 19, 636.

19 FLOWERS HH. The effects of X-irradiation on the biological activity of Cottonmouth Mocacasin (Agkistrodon piscivorus) venom. Toxicon, 1963, 1, 131-6.

20 GIROX E., LACHANN PJ. "In vivo" diminuition by chelators of snake venom provoked hemorrage and "in vitro" inhibition of proteolytic activity. Toxicon, 1981, 19, 481-92.

21 GUARNIERI-CRUZ MC., MURATA Y. Attenuation ob Bothrops jararaca venom by ionizing radiation. Toxicon, 1990, 28, 92-8.

22 GUIDOLIN R., DIAS DA SILVA W., HIGASHI HG., CARICATI CP., LIMA MLSR., MORAIS JF. Hiperimunização de cavalos soroprodutores com venenos botrópicos e crotálico tratados por glutaraldeido. Mem. Inst. Butantan, 1989, $51,85-90$.

23 HERRERA E., YARLEQUE A., CAMPOS S., ZAVALETA A. Gamma irradiation effect on biological activity and enzymatic properties of snake venoms. Inf. Nucl., 1986, 3, 1-14. 
R. S Ferreira Júnior et al. IMMUNIZATION WITH NATIVE AND COBALT 60-IRRADIATED Crotalus durissus terríificus VENOM IN SWISS MICE: ASSESSMENT OF THE NEUTRALIZING POTENCY OF ANTISERA. J. Venom. Anim. Toxins incl. Trop. Dis., 2005, 11, 3, p. 312

24 KAISER II., MIDDLEBROOK JL., CRUMRINE MHM., STEVENSON WW. Crossreativity and neutralization by rabbit antisera raised against crotoxin, its subunits and two related toxins. Toxicon, 1986, 24, 669-78.

25 KOCHOLATY WF., JOYCE C., GOETZ BD., THOMAS AB., LEDFORD EB. Immunogenic response of the venoms of Fer de Lance, Bothrops atrox asper, and La Cascabella, Crotalus durissus durissus, following photooxidative detoxification. Toxicon, 1968, 5, 153-8.

26 LEÓN G., VALVERDE JM., ROJAS G., LOMONTE B., GUTIÉRREZ JM. Comparative study on the ability of $\lg G$ and Fab sheep antivenoms to neutralize local hemorrhage, edema and myonecrosis induced by Bothrops asper (terciopelo) snake venom. Toxicon, 2000, 38, 233-44.

27 MARIA WS., PACHECO BG., BARBOSA CF., VELARDE DT., CHÁVEZOLÓRTEGUI C. Determination of the neutralizing potency of horse antibothropic and anticrotalic antivenoms in blood samples colleted on filter paper. Toxicon, 2001, 39, 1607-9.

28 MOROZ C., GOLDBLUM N., VRIES A. Preparation of Vipera palestinae antineurotoxin using carboximethyl-cellulose-bound neurotoxin as antigen. Nature, 1963, 16, 697-8.

29 MURATA Y., NISHIKAWA AK., NASCIMENTO N., HIGASHI HG., DIAS DA SILVA W., ROGERO JR. Gamma irradiation reduces the toxic activities of Crotalus durissus terrificus venom but does not affect their immunogenic activities. Toxicon, 1992, 28, 617.

30 NASCIMENTO N. Biochemical and immunological characterization of the main products of crotoxin irradiation. J. Venom. Anim. Toxins, 1996, 2, 169.

31 NASCIMENTO N., SEEBART C., FRANCIS B., ROGERO JR., KAISER II. Influence of ionizing radiation on crotoxin: biochemical and immunological aspects. Toxicon, 1996, 34, 123-31.

32 NASCIMENTO N., SPENCER PJ., ANDRADE Jr. HF. Effects of gamma radiation on snake venoms. Radiat. Phys. Chem., 1998, 52, 665-9.

33 NETTO DP., CHIACCHIO SB., BICUDO PL., ALFIERI AA., NASCIMENTO N. Humoral response and neutralization capacity of sheep serum inoculated with natural and Cobalt 60-irradiated Crotalus durissus terrificus venom (Laurenti, 1768). J. Venom. Anim. Toxins incl. Trop. Dis., 2002, 8, 297-314. 
R. S Ferreira Júnior et al. IMMUNIZATION WITH NATIVE AND COBALT 60-IRRADIATED Crotalus durissus terríificus VENOM IN SWISS MICE: ASSESSMENT OF THE NEUTRALIZING POTENCY OF ANTISERA. J. Venom. Anim. Toxins incl. Trop. Dis., 2005, 11, 3, p. 313

34 NETTO DP., CHIACCHIO SB., BICUDO PL., ALFIERI AA., NASCIMENTO N. Hematological changes in sheep inoculated with Crotalus durissus terrificus snake (Laurenti, 1768) venom irradiated with Cobalto ${ }^{60}$ and in the natural form. J. Venom. Anim. Toxins incl. Trop. Dis., 2004, 10, 34-52.

35 OGUIURA N., CAMARGO ME., DA SILVA ARP. Horton DSPQ. Quantification of crotamine, a small basic myotoxin, in South American rattlesnake (Crotalus durissus terrificus) venom by enzyme-linked immunosorbent assay with parallel-lines analysis. Toxicon, 2000, 38, 443-8.

36 ROGERO JR., NASCIMENTO N. Detoxification of snake venom using ionizing radiation. J. Venom. Anim. Toxins, 1995, 1, 7-10.

37 SCHEAFFER RC., RANDAL H., RESK J., CARLSON RW. Enzyme-linked immunosorbent assay (ELISA) of size selected crotalic venom antigens by Wyeth's polyvalent antivenom. Toxicon, 1988, 26, 67-76.

38 SELVANAYAGAM ZE., GOPALAKRISHNAKONE P. Tests for detection of snakes venoms, toxins and venom antibodies: review on recent trends (1987-1997). Toxicon, 1999, 37, 565-86.

39 SJOSTROM L., AL-ABDULLA IH., RAWAT S., SMITH DC., LANDON J. A comparasion of ovine and equine antivenoms. Toxicon, 1994, 32, 427-33.

40 SOUZA FAD., SPENCER PJ., ROGERO JR., NASCIMENTO N., DAL PAI-SILVA M., GALLACCI M. ${ }^{60} \mathrm{Co}$ gamma irradiation prevents Bothrops jararacussu venom neurotoxicity and myotoxicity in isolated mouse neuromuscular junction. Toxicon, 2002, 40, 1101-6.

41 SOUZA E SILVA MCC., GONÇALVES LRC., MARIANO M. The venom of South American rattlesnake inhibits macrophage function and is endowed with antiinflammatory properties. Mediat. Inflamm., 1996, 5, 18-23.

42 SOUZA FILHO JN., GUARNIERI-CRUZ MC., MURATA Y., ROGERO JR. Detoxification of the crotoxin complex gamma radiation. Braz. J. Med. Res., 1992, 25, 103-13.

43 SPENCER PJ. Biochemical and immunological alterations of ${ }^{60} \mathrm{Co}$ irradiated Bothrops jararacussu venom. J. Venom. Anim. Toxins, 1996, 2, 165.

44 TEJANSEN P., OTTOLENGHI A. The effect of ultra-violet light on the toxicity and enzymatic and antigenic activities of snake venom. Toxicon, 1970, 8, 225-33. 
R. S Ferreira Júnior et al. IMMUNIZATION WITH NATIVE AND COBALT 60-IRRADIATED Crotalus durissus terríificus VENOM IN SWISS MICE: ASSESSMENT OF THE NEUTRALIZING POTENCY OF ANTISERA. J. Venom. Anim. Toxins incl. Trop. Dis., 2005, 11, 3, p. 314

45 THEAKSTON RDG., LLOYD-JONES MJ., REID HA. Micro-ELISA for detecting and assying snake venom and venom-antibody. Lancet, 1977, 24, 639-41.

46 THEAKSTON RDG., WARREL DA., GRIFFITHS E. Report of a WHO workshop on the standardization and control of antivenoms. Toxicon, 2003, 41, 541-57. 